\title{
Quantitative analysis of macrophage inhibitory cytokine-I (MIC-I) gene expression in human prostatic tissues
}

\author{
T Nakamura', A Scorilas ${ }^{2}$, C Stephan ${ }^{1,3}$, GM Yousef ${ }^{1,4}$, G Kristiansen ${ }^{5}, K_{\text {Jung }}^{3}$ and EP Diamandis*,1,4 \\ 'Department of Pathology and Laboratory Medicine, Mount Sinai Hospital, Toronto, Ontario, Canada M5G IX5; ${ }^{2}$ National Center of Scientific Research \\ 'Demokritos', IPC, 15310 Athens, Greece; 'Department of Urology, University Hospital Charité, Humboldt University, D- I0098 Berlin, Germany; \\ ${ }^{4}$ Department of Laboratory Medicine and Pathobiology, University of Toronto, Toronto, Ontario, Canada M5G IL5; ${ }^{5}$ Department of Pathology, University \\ Hospital Charité, Humboldt University D-10098 Berlin, Germany
}

\begin{abstract}
Macrophage inhibitory cytokine-I (MIC-I) gene is a member of transforming growth factor- $\beta$ superfamily and was reported to be highly overexpressed in human prostate cancer using microarray technology. The aim of this study was to evaluate the quantitative expression of MIC-I in malignant and benign prostate tissues and to associate expression levels with clinicopathological parameters of prostate cancer. Matched (paired) prostatic tissue samples from the cancerous and noncancerous parts of the same prostates were obtained from 66 patients who underwent radical prostatectomy. Quantitative RT-PCR was performed using SYBR Green I on the Roche LightCycler ${ }^{\text {TM }}$ system. Macrophage inhibitory cytokine- I gene overexpression in cancerous tissues was observed in $88 \%$ of cases, compared to noncancerous tissues $(P<0.00 \mathrm{I})$. The expression level of $\mathrm{MIC}-\mathrm{I}$ in cancerous tissues was significantly higher than in noncancerous tissue $(P<0.00 \mathrm{I})$. Higher expression of $\mathrm{MIC}-\mathrm{I}$ gene was significantly associated with higher Gleason score $(P=0.004)$. The expression of the MIC-I gene in prostate cancer is significantly higher than in noncancerous tissues, especially in more aggressive forms of the disease (Gleason score $>5$ ). This is in contrast to prostate-specific antigen that is downregulated in higher-grade tumours. The upregulation of MIC-I in prostate cancer and in advanced and more aggressive prostatic tumours suggests that MIC-I protein should be evaluated as a potential diagnostic and prognostic biomarker.

British Journal of Cancer (2003) 88, I I0I- I 104. doi:I0.1038/sj.bjc.6600869 www.bjcancer.com

(C) 2003 Cancer Research UK
\end{abstract}

Keywords: macrophage inhibitory factor-I; prostate cancer; quantitative RT-PCR

Prostate cancer is the most common cancer of North American men. Prostate-specific antigen (PSA), also known as human kallikrein 3 (hK3), according to the approved new nomenclature of the human kallikrein family (Diamandis et al, 2000a), is used for early detection and monitoring of prostate cancer (Bilhartz et al, 1991; Oesterling, 1991; Diamandis et al, 2000b). However, nonmalignant prostatic diseases, especially benign prostatic hyperplasia (BPH) and acute prostatitis, also cause serum PSA elevation, thus complicating the diagnosis of prostatic cancer by PSA measurements alone (Polascik et al, 1999). The evaluation of the molecular forms of PSA improves the specificity of PSA (Mitchell et al, 2001; Stephan et al, 2002). Despite the availability of these tests, there is an urgent need for new biomarkers for early detection of prostate cancer. In accordance with the principles of the development of new biomarkers (Sullivan Pepe et al, 2001), one approach would be to search for genes that are overexpressed in prostate cancer.

The macrophage inhibitory cytokine-1 (MIC-1) gene is a member of transforming growth factor- $\beta$ (TGF- $\beta$ ) superfamily

\footnotetext{
*Correspondence: Dr EP Diamandis, Mount Sinai Hospital, Department of Pathology and Laboratory Medicine, 600 University Avenue, Toronto, Ontario, Canada M5G IX5; E-mail: ediamandis@mtsinai.on.ca

Received 16 September 2002; revised 15 January 2003; accepted 4 February 2003
}

and was originally isolated from macrophages using the cDNA subtraction method (Bootcov et al, 1997). The macrophage inhibitory cytokine-1 gene is also known as growth/differentiation factor-15 (Bottner et al, 1999) and placental bone morphogenetic protein (PLAB) (Hromas et al, 1997; Thomas et al, 2001). Recent reports, using DNA microarray technology, have shown that the MIC-1 gene is more highly expressed in prostate cancer than in BPH tissues (Buckhaults et al, 2001; Welsh et al, 2001). Until now, there are no quantitative expression data on relatively large groups of patients.

The aim of this study was to investigate the expression of MIC-1 in cancerous and matched noncancerous prostate tissues by quantitative RT - PCR and associate these data with clinicopathological parameters of prostate cancer patients.

\section{MATERIALS AND METHODS}

\section{Study group}

Included in this study were 66 patients who had undergone radical retropubic prostatectomy for prostatic adenocarcinoma at the Charité University Hospital, Berlin, Germany. Patient ages ranged from 48 to 73 years with a mean of 62.7 and a median of 64 years. The patients did not receive any hormonal or other therapy before surgery. 


\section{Prostate cancer tissues}

Fresh prostate tissue samples were obtained from the cancerous and noncancerous parts of the same prostates. Small pieces of tissue were gross dissected by an experienced pathologist (GK) immediately after removal of the prostate, snap frozen and stored in liquid nitrogen until analysis, as described previously (Meyer et al, 1997). Histological analysis of paraffin-embedded tissue adjacent to these samples was performed by the same pathologist to verify the diagnoses. Only tumour samples that were fully surrounded by malignant tissue according to this analysis were used in this study. We also discarded samples in which benign prostate glands made up more than $10 \%$ of the tissue. This way, we minimised the contamination of the tumour sample with benign glands, which is not fully avoidable in prostate cancer unless microdissected tissues were processed. Most of the tumours were located dorsolaterally in the peripheral zone of the prostate. The tissue that we considered as normal was usually taken from the inner zone of the contralateral lobe. Histologically, many of these samples displayed a mild glandular hyperplasia. The criteria of exclusion were prominent inflammatory infiltrates, lack of epithelia due to stromal hyperplasia and prostatic intraepithelial neoplasia. The Ethics Committee of the Charite Hospital approved the use of these tissues for research purposes.

\section{Total RNA extraction and cDNA synthesis}

Tumour tissues were minced with a scalpel, on dry ice, and transferred immediately to $2 \mathrm{ml}$ polypropylene tubes. They were then homogenised and total RNA was extracted using the RNeasy ${ }^{\mathbb{R}}$ total RNA isolation system, following the manufacturer's instructions (Qiagen, Valencia, CA, USA). The concentration and purity of RNA were determined spectrophotometrically. Two micrograms of total RNA were reverse-transcribed into first strand cDNA using the Superscript ${ }^{\mathrm{TM}}$ preamplification system (Gibco BRL, Gaithersburg, MD, USA). The final volume was $20 \mu \mathrm{l}$.

\section{Quantitative real-time RT-PCR analysis}

Two gene-specific primers were designed (MIC-1/F: 5' CGC GCA ACG GGG ACG ACT $3^{\prime}$ and MIC-1/R: $5^{\prime}$ TGA GC ACC ATG GGA TTG TAG C $3^{\prime 11}$ ). Real-time monitoring of PCR reactions was performed using the LightCycler ${ }^{\mathrm{TM}}$ system (RocheApplied Science, Indianapolis, IN, USA) and the SYBR green I dye, which binds preferentially to double-stranded DNA. Fluorescence signals, which are proportional to the concentration of the PCR product, are measured at the end of each cycle and displayed on a computer screen (Buckhaults et al, 2001). The reaction is characterised by the point during cycling when amplification of PCR products is first detected, rather than the amount of PCR product accumulated after a fixed number of cycles. The higher the starting quantity of the template, the earlier a significant increase in fluorescence is observed (Wittwer et al, 1997; Bieche et al, 1999). The threshold cycle is defined as the fractional cycle number at which fluorescence passes a fixed threshold above baseline (Bieche et al, 1998).

\section{Endogenous control}

For each sample, the amount of the target and of $\beta$ actin, as an endogenous control, was determined using a calibration curve. The amount of the target molecule was then divided by the amount of the endogenous reference, to obtain a normalised target value (Bieche et al, 1999).

\section{Calibration curves}

Separate calibration (standard) curves for actin and MIC-1 were constructed using serial dilutions of total cDNA from a healthy human prostate tissue, purchased from Clontech, Palo Alto, CA, USA. The standard curve samples were included in each run. Standards for both MIC-1 and actin RNAs were defined to contain an arbitrary starting concentration, since no primary calibrators exist. Hence, all calculated concentrations are relative to the concentration of the standard.

\section{PCR amplification}

The PCR reaction was carried out on the LightCycler ${ }^{\mathrm{TM}}$ system. For each run, a master mixture was prepared on ice, containing $1 \mu \mathrm{l}$ of cDNA, $2 \mu \mathrm{l}$ of LC DNA Master SYBR Green I mix, $50 \mathrm{ng}$ of primers and $2.4 \mu \mathrm{l}$ of $25 \mathrm{~mm} \mathrm{MgCl}$. The final volume was adjusted with $\mathrm{H}_{2} \mathrm{O}$ to $20 \mu \mathrm{l}$. After the reaction mixture was loaded into a glass capillary tube, the cycling conditions were carried out as follows: initial denaturation at $95^{\circ} \mathrm{C}$ for $10 \mathrm{~min}$, followed by 42 cycles of denaturation at $95^{\circ} \mathrm{C}$ for $1 \mathrm{~s}$, annealing at $58^{\circ} \mathrm{C}$ for $8 \mathrm{~s}$ and extension at $72^{\circ} \mathrm{C}$ for $30 \mathrm{~s}$. The temperature transition rate was set at $20^{\circ} \mathrm{C} \mathrm{s}^{-1}$. Fluorescent product was measured by a single acquisition mode at $92^{\circ} \mathrm{C}$ after each cycle.

\section{Melting curve}

For distinguishing specific from nonspecific products and primer dimers, a melting curve was obtained after amplification by holding the temperature at $70^{\circ} \mathrm{C}$ for $30 \mathrm{~s}$ followed by a gradual increase in temperature to $99^{\circ} \mathrm{C}$ at a rate of $0.2^{\circ} \mathrm{C} \mathrm{s}^{-1}$, with the signal acquisition mode set at step, as described. To verify the melting curve results, representative samples of the PCR products were run on $1.5 \%$ agarose gels, purified, and cloned into the $\mathrm{pCR}$ 2.1-TOPO vector (Invitrogen, Carlsbad, CA, USA) according to the manufacturer's instructions. The inserts were sequenced from both directions using vector-specific primers, with an automated DNA sequencer.

\section{Statistical analysis}

Statistical analysis was performed with SAS software (SAS Institute, Cary, NC, USA). The analyses of differences between MIC-1 expression in noncancerous and cancerous tissues were performed with the nonparametric McNemar test and the Wilcoxon signed ranks test. The binomial distribution was used to compute the significance level of the McNemar test. Relations between different variables were assessed by the Mann-Whitney $U$-test.

\section{RESULTS}

\section{Expression level of MIC-1 in prostatic tissues}

We assessed the quantitative expression of MIC-1 mRNA in the 66 matched pairs of cancerous and noncancerous prostatic tissues. The expression levels of MIC-1 were expressed in arbitrary units, according to a standard curve that was constructed by using serial dilutions of a cDNA obtained from normal prostatic tissue. Results were then normalised by using the ratio of $\mathrm{MIC}-1 / \beta$-actin concentration for each sample.

Fifty eight cases showed higher expression level of MIC-1 gene in cancerous prostatic tissues in comparison with noncancerous tissues. Lower expression in cancer was observed in only eight cases. This difference was statistically significant $(P<0.001)$ (Table 1 and Figure 1). The expression levels of MIC-1 gene in cancerous prostatic tissues were significantly higher than that in noncancerous prostatic tissues. Results are summarized in Table 2 
Table I MIC-I expression in pairs of noncancerous and cancerous prostatic tissues

\begin{tabular}{lcc}
\hline MIC expression & Number of patients (\%) & $\boldsymbol{P}_{\text {-value }}$ \\
\hline Higher in cancer vs normal & $58(88)$ & $<0.001$ \\
Lower in cancer vs normal & $8(12)$ & \\
\hline
\end{tabular}

${ }^{\mathrm{a} C}$ Calculated by McNemar test.

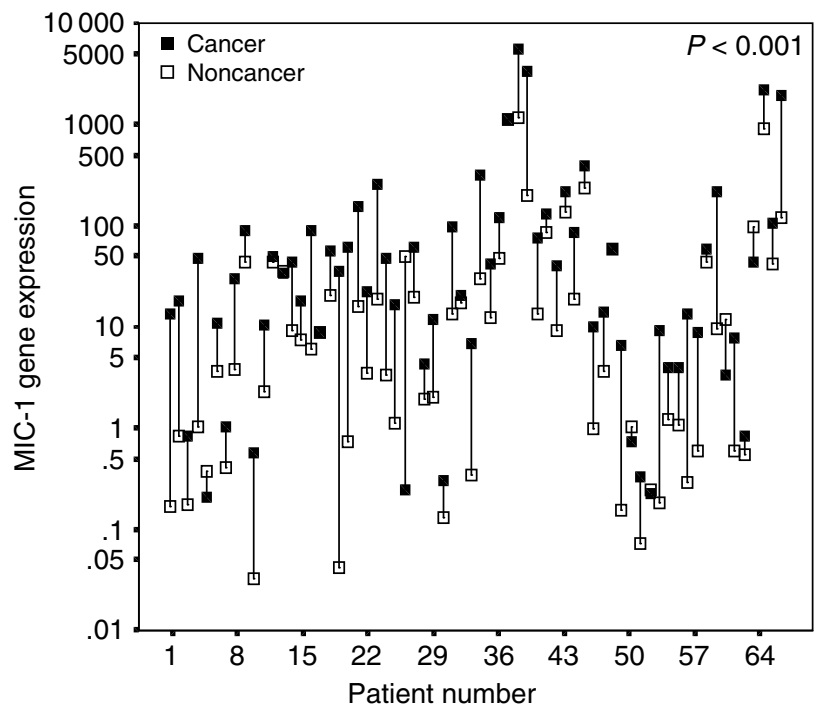

Figure I MIC-I mRNA expression as arbitrary units shown for 66 patients. The black box represents the level in cancerous tissue and the connected white box the respective level of the nonmalignant tissue of the same patient. The $P$-value was calculated by McNemar test.

and Figure 2. Mean and median values of MIC-1 transcripts were significantly higher in the cancerous tissues by approximately $273-375 \%(P<0.001)$.

\section{Association with clinicopathological parameters}

The association of MIC-1 mRNA level with clinicopathological parameters in cancerous tissues is shown in Table 3. The expression levels of MIC-1 gene did not show any significant association with tumour stage $(P=0.69)$ and tumour grade $(P=0.86)$. On the other hand, higher Gleason score $(>5 v s \leqslant 5)$ significantly associated with higher MIC-1 gene expression.

\section{DISCUSSION}

Prostate-specific antigen, also known as $\mathrm{hK} 3$, and its molecular forms are the most useful tumour markers for the prostate cancer

Table 2 Descriptive statistics for MIC-I expression (mRNA levels) in noncancerous and cancerous prostatic tissues

\begin{tabular}{|c|c|c|c|c|c|}
\hline & Mean $^{a}$ & $\begin{array}{l}\text { Standard } \\
\text { error }^{\mathbf{a}}\end{array}$ & Median $^{\mathbf{a}}$ & Range $^{a}$ & $P$-value ${ }^{b}$ \\
\hline $\begin{array}{l}\text { MIC, noncancer }(\mathrm{N}=66) \\
\text { MIC, cancer }(\mathrm{N}=66) \\
\% \text { Increase }^{\mathrm{C}}\end{array}$ & $\begin{array}{l}71 \\
264 \\
273 \%\end{array}$ & $\begin{array}{r}27 \\
106 \\
-\end{array}$ & $\begin{array}{l}6.7 \\
32 \\
375 \%\end{array}$ & $\begin{array}{l}0.03-116 \\
0.21-5581\end{array}$ & $<0.001$ \\
\hline
\end{tabular}

These values are corrected for actin expression and are unitless ratios. ${ }^{b}$ Calculated by the Wilcoxon's signed rank test. ' Compared to cancer and assuming that the value in noncancerous tissue is $100 \%$.

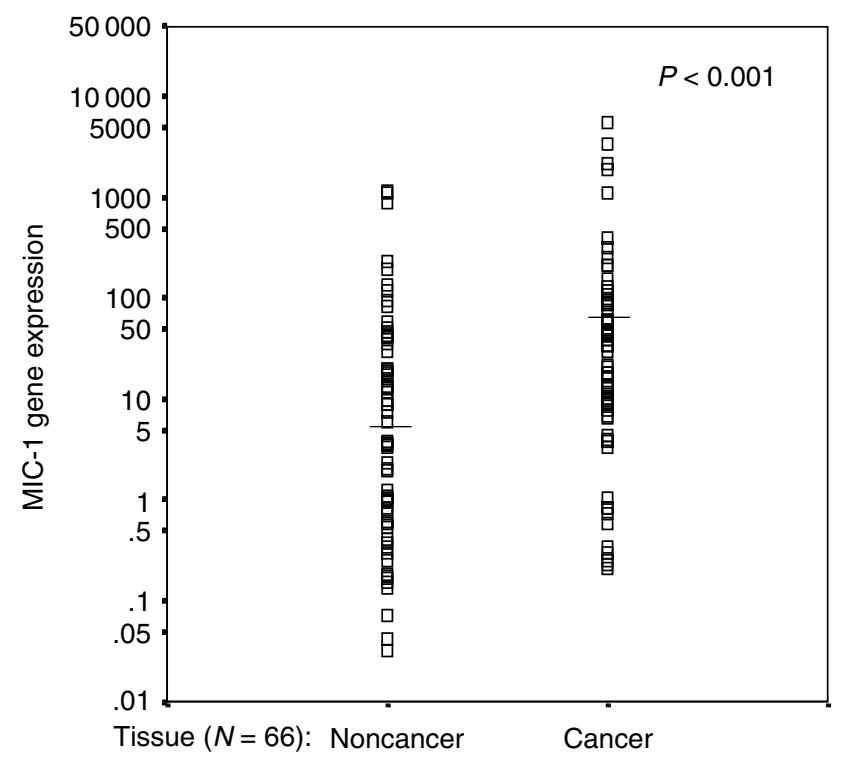

Figure 2 MIC-I mRNA expression in cancerous and noncancerous prostatic tissues. The horizontal lines indicate the median. The $P$-value was calculated by the Mann-Whitney U-test.

Table 3 MIC expression in cancerous prostatic tissues from 66 patients classified by stage of the disease, Gleason score and tumour grade

\begin{tabular}{lccccc}
\hline & Total & Mean $^{\mathbf{a}}$ & Standard Error $^{\mathbf{a}}$ & Median $^{\mathbf{a}}$ & $\boldsymbol{P}_{\text {-value }}{ }^{\mathbf{b}}$ \\
\hline Stage & & & & & \\
I/II & 32 & 145 & 67 & 10 & 0.69 \\
III & 34 & 376 & 195 & 37 & \\
Gleason score & & & & & \\
$\quad \leqslant 5$ & 21 & 117 & 90 & 9 & 0.004 \\
$>5$ & 40 & 373 & 167 & 54 & \\
Unknown & 5 & & & & \\
Grade & & & & & \\
GI/2 & 39 & 114 & 50 & 22 & 0.86 \\
G3 & 27 & 482 & 246 & 40 & \\
\hline
\end{tabular}

${ }^{a}$ These values are corrected for actin expression and are unitless ratios. ${ }^{b}$ Calculated by the Mann-Whitney U-test.

and hK2, another member of the kallikrein gene family, may help in reducing the number of unnecessary biopsies (Rittenhouse et al, 1998). Nevertheless, these serum biomarkers cannot accurately predict the presence of prostate cancer, its aggressiveness or the rate of postoperative PSA failure. New, improved biomarkers might be necessary especially for Gleason 4/5 tumours (Stamey, 2001).

The MIC-1 gene was originally cloned from macrophages using a subtraction-cloning strategy (Bootcov et al, 1997). This gene is a member of the TGF- $\beta$ superfamily. Other investigators discovered this gene independently and gave it different names, such as growth/differentiation factor-15 (GDF-15) (Bottner et al, 1999) and prostate differentiation factor (PLAB) (Hromas et al, 1997; Thomas et al, 2001).

Recently, the MIC-1 gene was found to be highly overexpressed in human prostate (Welsh et al, 2001) and colorectal cancer (Buckhaults et al, 2001) by microarray technology. To confirm these results, and investigate the association with clinicopathological parameters, we assessed the quantitative expression of MIC-1 
in a relatively large number of matched prostate cancerous and noncancerous tissues using LightCycler ${ }^{\mathrm{TM}}$ technology. Our results showed that MIC-1 gene expression was significantly higher in cancerous prostatic tissue than in noncancerous tissue. Higher Gleason score $(>5)$ cancer expressed significantly more MIC-1 mRNA (Table 3). These data suggest that MIC-1 gene expression is increased in cancer tissue, compared to normal tissue and its expression is increased when the tumour progresses further. Thus, the level of MIC-1 expression may be a marker of tumour differentiation.

Transforming growth factor- $\beta$ and its receptor were found to be overexpressed in high-grade prostatic intraepithelial neoplasia in the rat ventral prostate. It was reported that high expression of TGF- $\beta$ and its receptors enhance cancer growth and metastasis and are associated with poor prognosis (Wong et al, 2000). Preoperative plasma TGF- $\beta$ levels are markedly elevated in men with prostate cancer metastasis and are a strong predictor of biological progression after surgery (Shariat et al, 2001). The macrophage migration inhibitory factor (MIF) gene was reported to be elevated in prostate cancer tissues and upregulation of this gene is associated with serum level of MIF (Meyer-Siegler et al, 2002).

In conclusion, we report upregulation of the MIC-1 gene in prostate cancer and in advanced and more aggressive prostatic tumours. These data may indicate a possible role for the MIC-1 protein as a future diagnostic and prognostic biomarker. Furthermore, the understanding of the biological function of MIC-1 in prostate may help in delineating its role in prostatic physiology and pathobiology.

\section{ACKNOWLEDGEMENTS}

We thank Dr Monika Jung (University Hospital Charité, Humboldt University, Berlin, Germany) for her technical advice on the quantitative RT-PCR method.

\section{REFERENCES}

Bieche I, Olivi M, Champeme MH, Vidaud D, Lidereau R, Vidaud M (1998) Novel approach to quantitative polymerase chain reaction using realtime detection: application to the detection of gene amplification in breast cancer. Int J Cancer 78: 661-666

Bieche I, Onody P, Laurendeau I, Olivi M, Vidaud D, Lidereau R, Vidaud M (1999) Real-time reverse transcription-PCR assay for future management of ERBB2-based clinical applications. Clin Chem 45: 1148-1156

Bilhartz DL, Tindall DJ, Oesterling JE (1991) Prostate-specific antigen and prostatic acid phosphatase: biomolecular and physiologic characteristics. Urology 38: $95-102$

Bootcov MR, Bauskin AR, Valenzuela SM, Moore AG, Bansal M, He XY, He XY, Zhang HP, Donnellan M, Mahler S, Pryor K, Walsh BJ, Nicholson RD, Fairlie WD, Por SB, Robbins JM, Breit SN (1997) MIC-1, a novel macrophage inhibitory cytokine, is a divergent member of the TGF-beta superfamily. Proc Natl Acad Sci USA 94: 11514-11519

Bottner M, Suter-Crazzolara C, Schober A, Unsicker K (1999) Expression of a novel member of the TGF-beta superfamily, growth/differentiation factor-15/macrophage-inhibiting cytokine-1 (GDF-15/MIC-1) in adult rat tissues. Cell Tissue Res 297: 103-110

Buckhaults P, Rago C, St Croix B, Romans KE, Saha S, Zhang L, Vogelstein B, Kinzler KW (2001) Secreted and cell surface genes expressed in benign and malignant colorectal tumors. Cancer Res 61: 6996-7001

Diamandis EP, Yousef GM, Clements J, Ashworth LK, Yoshida S, Egelrud T, Nelson PS, Shiosaka S, Little S, Lilja H, Stenman UH, Rittenhouse HG, Wain H (2000a) New nomenclature for the human tissue kallikrein gene family. Clin Chem 46: $1855-1858$

Diamandis EP, Yousef GM, Luo LY, Magklara A, Obiezu CV (2000b) The human kallikrein gene family - implications in carcinogenesis. Trends Endocrinol Metab 11: 54-60

Hromas R, Hufford M, Sutton J, Xu D, Li Y, Lu L (1997) PLAB, a novel placental bone morphogenetic protein. Biochim Biophys Acta 1354: 40 44

Meyer A, Jung K, Lein M, Rudolph B, Schnorr D, Loening SA (1997) Factors influencing the ratio of free to total prostate-specific antigen in serum. Int J Cancer 74: 630-636

Meyer-Siegler KL, Bellino MA, Tannenbaum M (2002) Macrophage migration inhibitory factor evaluation compared with prostate specific antigen as a biomarker in patients with prostate carcinoma. Cancer 94: $1149-1156$

Mitchell ID, Croal BL, Dickie A, Cohen NP, Ross I (2001) A prospective study to evaluate the role of complexed prostate specific antigen and free/total prostate specific antigen ratio for the diagnosis of prostate cancer. J Urol 165: $1549-1553$

Oesterling JE (1991) Prostate specific antigen: a critical assessment of the most useful tumor marker for adenocarcinoma of the prostate. J Urol 145: $907-923$

Polascik TJ, Oesterling JE, Partin AW (1999) Prostate specific antigen: a decade of discovery - what we have learned and where we are going. J Urol 162: 293-306

Rittenhouse HG, Finlay JA, Mikolajczyk SD, Partin AW (1998) Human kallikrein 2 (hK2) and prostate-specific antigen (PSA): two closely related, but distinct, kallikreins in the prostate. Crit Rev Clin Lab Sci 35: $275-368$

Shariat SF, Shalev M, Menesses-Diaz A, Kim IY, Kattan MW, Wheeler TM, Slawin KM (2001) Preoperative plasma levels of transforming growth factor beta(1) (TGF-beta(1)) strongly predict progression in patients undergoing radical prostatectomy. J Clin Oncol 19: $2856-2864$

Stamey TA (2001) Preoperative serum prostate-specific antigen (PSA) below $10 \mathrm{microg} / \mathrm{l}$ predicts neither the presence of prostate cancer nor the rate of postoperative PSA failure. Clin Chem 47: 631-634

Stephan C, Jung K, Diamandis EP, Rittenhouse HG, Lein M, Loening SA (2002) Prostate-specific antigen, its molecular forms and other kallikrein markers for detection of prostate cancer. Urology 59: 2-8

Sullivan Pepe M, Etzioni R, Feng Z, Potter JD, Thompson ML, Thornquist M, Winget M, Yasui Y (2001) Phases of biomarker development for early detection of cancer. J Natl Cancer Inst 93: 1054-1061

Thomas R, True LD, Lange PH, Vessella RL (2001) Placental bone morphogenetic protein (PLAB) gene expression in normal, premalignant and malignant human prostate: relation to tumor development and progression. Int $J$ Cancer 93: $47-52$

Welsh JB, Sapinoso LM, Su AI, Kern SG, Wang-Rodriguez J, Moskaluk CA, Frierson Jr HF, Hampton GM (2001) Analysis of gene expression identifies candidate markers and pharmacological targets in prostate cancer. Cancer Res 61: 5974-5978

Wittwer CT, Herrmann MG, Moss AA, Rasmussen RP (1997) Continuous fluorescence monitoring of rapid cycle DNA amplification. Biotechniques 22: $130-138$

Wong YC, Xie W, Tsao SW (2000) Structural changes and alteration in expression of TGF-beta1 and its receptors in prostatic intraepithelial neoplasia (PIN) in the ventral prostate of noble rats. Prostate 45: 289298 